\title{
An Abrasion, a Prosthetic Shoulder, and a Cat with a Licking Tendency: Case Report and Literature Review of $P$. multocida Joint Seeding
}

\author{
William F. Abel $\mathbb{D},{ }^{1}$ Christopher S. Eckman, ${ }^{2}$ Robert P. Summers, ${ }^{1}$ William S. Sessions $\mathbb{D}^{2}{ }^{2}$ \\ and Amanda E. Schnee ${ }^{3}$ \\ ${ }^{1}$ University of South Carolina School of Medicine Greenville, 607 Grove Rd., Greenville, SC 29605, USA \\ ${ }^{2}$ Prisma Health Upstate Department of Medicine, 701 Grove Rd., Greenville, SC 29605, USA \\ ${ }^{3}$ Prisma Health Upstate Department of Infectious Disease, 701 Grove Rd., Greenville, SC 29605, USA
}

Correspondence should be addressed to William F. Abel; wabel@email.sc.edu

Received 6 February 2020; Revised 23 October 2020; Accepted 4 November 2020; Published 18 November 2020

Academic Editor: George N. Dalekos

Copyright (c) 2020 William F. Abel et al. This is an open access article distributed under the Creative Commons Attribution License, which permits unrestricted use, distribution, and reproduction in any medium, provided the original work is properly cited.

\begin{abstract}
Pasteurella multocida is a pathogen well known for its zoonotic transmission, most commonly by cats and dogs. When bacteremia ensures from an infection, patients with foreign objects present in their bodies, including prosthetic joints and mesh implants, become vulnerable to seeding. There have been multiple documented cases in which $P$. multocida bacteremia has resulted in infection of both native and prosthetic joints. Furthermore, cases have been documented in which patients with $P$. multocida bacteremia have developed meningitis and neurological complications. Here, we present a patient with multiple comorbidities including multifactorial immunocompromise, advanced age, and multiple prosthetic joints who developed prosthetic joint infection and spinal osteomyelitis after the development of Pasteurella bacteremia. Aggressive treatment was undertaken given her risk factors, and a combination of antibiotics and surgery was utilized, with the patient making a full recovery.
\end{abstract}

\section{Background}

Pasteurella multocida was first isolated by Louis Pasteur in 1880. Since that time, it has been demonstrated as a common source of zoonotic infection with $P$. multocida isolated in up to $50 \%$ of dog bites and $75 \%$ of cat bites [1]. P. multocida infection has also been documented in the absence of bite wounds in patients with cat scratches present on physical examination [2]. Less commonly still are instances in which P. multocida is isolated from an individual where no wounds from animals are detected [3,4]. We present a case of $P$. multocida bacteremia in an immunocompromised patient, with a history of close contact with both cats and dogs but no bites or scratches, resulting in subsequent septic arthritis of the shoulder, epidural abscess, and spinal osteomyelitis. We reviewed the available literature on P. multocida and pathogenicity, antibiotic susceptibility profiles, and propensity for metastatic foci of infection.

\section{Case Presentation}

A 67-year-old female with a past medical history of multiple myeloma status postautologous stem cell transplant 4 years prior with evidence of stringent complete response and maintained on lenalidomide presented with wrist pain, fevers, and altered mental status. The patient had been well until two days prior when she fell at home. She was found by a home aide to be confused, febrile, and with a swollen right wrist. Significant surgical history included bilateral knee surgeries, left shoulder arthroplasty, and right total hip arthroplasty. She reported living with a roommate and numerous domestic cats and dogs.

In the emergency department, presenting vital signs revealed blood pressure $86 / 44 \mathrm{mmHg}$, temperature $101.1 \mathrm{~F}$, heart rate 128, and oxygen saturation $94 \%$ on 3 liters nasal cannula. Examination of the patient revealed her to be alert and oriented only to herself. Respiratory examination 
revealed good air movement and normal breath sounds. The ulnar aspect of her right wrist revealed a small abrasion with mild erythema. The right wrist was edematous and tender to palpation. She had decreased strength and range of motion in the right wrist, but normal elbow and shoulder joints. There were no signs of otherwise broken or punctured skin. The remainder of her musculoskeletal examination was unremarkable.

Initial complete blood count revealed a white blood cell count of $5.0 \mathrm{Th} / \mathrm{mm}^{3}$ (normal limit $4.0-11.0 \mathrm{Th} / \mathrm{mm}^{3}$ ), hemoglobin $10.4 \mathrm{~g} / \mathrm{dL}$ (grams/deciliter) (normal limit $12.0-16.0 \mathrm{~g} / \mathrm{dL}$ ), platelets $132.0 \mathrm{Th} / \mathrm{mm}^{3}$ (normal limit $150-400 \mathrm{Th} / \mathrm{mm}^{3}$ ), and $21 \%$ bands (normal limit $3-5 \%$ ). Complete metabolic panel was significant for sodium $126 \mathrm{mMol} / \mathrm{L}$ (millimoles per liter) (normal limit 136-145 mMol/L), AST $213 \mathrm{IU} / \mathrm{L}$ (international units per liter) (normal limit 8-20 IU/L), ALT 57 IU/L (normal limit 8-20 IU/L), and alkaline phosphatase $479 \mathrm{IU} / \mathrm{L}$ (normal limit 20-70 IU/L). Erythrocyte sedimentation rate and C-reactive protein were $104 \mathrm{~mm} / \mathrm{hr}$ (normal limit $0-20 \mathrm{~mm} / \mathrm{hr}$ ) and $237 \mathrm{mg} / \mathrm{L}$ (normal limit $<10 \mathrm{mg} / \mathrm{L}$ ), respectively. Procalcitonin was $5.48 \mathrm{ng} / \mathrm{mL}$ (normal limit $<0.05 \mathrm{ng} / \mathrm{mL}$ ). Urinalysis returned negative for leukocyte esterase and nitrite, and moderate blood was noted. Blood, urine, and stool cultures were obtained. Lumbar puncture was attempted twice unsuccessfully. Aspiration of the right wrist resulted in a dry tap. Empiric antibiotic coverage with vancomycin and ceftriaxone was initiated. Table 1 illustrates lab values from the patient's admission.

Radiographs of the chest as well as the right wrist (Figure 1), elbow, and humerus were obtained. Computed tomography (CT) of the head, abdomen, and pelvis were also obtained. Right upper extremity radiographs revealed no acute osseous or soft tissue abnormalities, and chest radiograph revealed clear lungs. CT imaging revealed no intracranial abnormalities but did note fluid levels in frothy secretions in the paranasal sinuses, as well as nonspecific perinephric edema and thickening of the renal pelvis bilaterally.

The patient's blood cultures grew Pasteurella multocida in both sets of bottles. Susceptibilities included amoxicillinclavulanate, ampicillin, ceftriaxone, levofloxacin, penicillin, and tetracycline. The organism was noted to be resistant to trimethoprim-sulfamethoxazole. Respiratory, stool, and urine cultures were negative. Antibiotic therapy was deescalated to monotherapy with ceftriaxone. Repeat blood cultures were obtained on hospital day four and were without growth.

On hospital day seven, the patient reported worsening left shoulder pain, the site of her previous left total shoulder arthroplasty. Magnetic resonance imaging (MRI) (Figure 1) revealed the presence of a small perihardware collection. Aspiration was performed, revealing approximately 70,000 white blood cells without crystals, and no subsequent growth on either aerobic or anaerobic cultures. Arthroscopy revealed purulent drainage from the anterior left shoulder, and subsequent lavage was performed by orthopedics out of concern for septic arthritis. Thick, purulent material was noted intraoperatively, but cultures remained without growth.

On hospital day ten, the patient reported an acute worsening in pain and feeling overall unwell. Physical exam revealed extreme point tenderness to palpation of her cervical and lumbar spine. MRIs of the spine (Figure 1) revealed multilevel osteomyelitis and septic arthritis of the facet joints L3-S1 bilaterally, as well as edema of the paraspinous soft tissues with epidural abscess. Laminectomy with incision and drainage was performed, and subsequent cultures revealed no growth. Additional imaging with contrast further demonstrated septic arthritis and epidural abscess.

The patient was able to be successfully discharged to a rehabilitation facility with the follow-up arranged with infectious disease and orthopedic specialists. She was continued on levofloxacin at discharge to complete a total of 6 weeks of therapy.

\section{Discussion}

P. multocida is a Gram-negative organism found as a member of the normal flora in the oropharynx and nasopharynx of cats, dogs, cattle, and mice [5]. With $38.4 \%$ of households owning dogs and $25.4 \%$ of households owning cats in the United States, this is an organism that a relatively large proportion of the population is exposed to on a daily basis [6]. Of particular relevance is the danger of infection with $P$. multocida progressing to bacteremia, which has mortality rates up to $30 \%$ [7].

3.1. Virulence Factors. P. multocida possesses a number of virulence factors known to facilitate various diseases in both humans and animals. LPS (lipopolysaccharide) from $P$. multocida has been shown to cause hemorrhagic septicemia in ungulates, cholera in avian species, and atrophic rhinitis in pigs [8]. While there are no known exotoxins produced, the polysaccharide capsule is important for protection from host immune defenses, and the filamentous hemagglutinin surface adhesin allows for adherence to structures [8]. There are 5 capsular serogroups and 16 Heddleston serovars, with A:1 and A:3 (serogroup: serovar) being most commonly transmitted from cats to humans [9]. $P$. multocida possesses the ability to produce biofilms, although this ability depends on the conditions present and interferes with the production of serogroup A capsule [10]. It would seem plausible, then, that in an immunosuppressed host such as in our case, the need for capsule production to evade immune response would be lessened, allowing for the production of biofilms and potentially the ability to seed multiple sites within the same host. The ability to form biofilms in these hosts may also speak to the need for longer durations of therapy, more aggressive interventions where foreign bodies are involved, and the consideration for suppressive therapy in settings where foreign bodies cannot be removed. This hypothesis is substantiated by a case report by Guilbart et al. [11], where they report a patient who suffered fatal septicemia related to $P$. multocida cellulitis 
TABLE 1: Laboratory values from the patient's hospital admission.

\begin{tabular}{|c|c|c|c|c|c|c|c|c|c|c|c|c|}
\hline Hospital day & Day 1 & Day 2 & Day 3 & Day 4 & Day 5 & Day 6 & Day 7 & Day 8 & Day 9 & Day 10 & Day 11 & Day 20 \\
\hline WBC & 9.9 & 7.1 & 14.1 & 14.1 & 11.5 & 10.7 & 9 & 10 & 10.4 & 8.3 & 8.7 & 6.0 \\
\hline $\mathrm{RBC}$ & 2.8 & 2.76 & 2.9 & 3.06 & 2.65 & 3.01 & 3.05 & 2.92 & 2.81 & 2.7 & 2.81 & 2.69 \\
\hline Hemoglobin & 9.6 & 9.1 & 9.7 & 9.9 & 8.8 & 9.8 & 9.9 & 9.7 & 9.3 & 8.6 & 9.3 & 8.5 \\
\hline Hematocrit & 26.7 & 26.7 & 26.9 & 28 & 24.5 & 28.3 & 28.3 & 28.5 & 27.7 & 26.8 & 27.9 & 26.3 \\
\hline $\mathrm{MCV}$ & 95.4 & 96.7 & 92.8 & 91.5 & 92.5 & 94 & 92.8 & 97.6 & 98.6 & 99.3 & 99.3 & 97.8 \\
\hline $\mathrm{MCH}$ & 34.3 & 33 & 33.4 & 32.4 & 33.2 & 32.6 & 32.5 & 33.2 & 33.1 & 31.9 & 33.1 & 31.6 \\
\hline $\mathrm{MCHC}$ & 36 & 34.1 & 36.1 & 35.4 & 35.9 & 34.6 & 35 & 34 & 33.6 & 32.1 & 33.3 & 232.3 \\
\hline RDW & 13.9 & 14.3 & 14 & 14.4 & 14.5 & 14.6 & 14.1 & 14.5 & 13.9 & 13.7 & 13.2 & 13.6 \\
\hline Platelets & 125 & 109 & 159 & 256 & 256 & 311 & 340 & 331 & 360 & 358 & 335 & 255 \\
\hline MPV & 9.5 & 9.9 & 10 & 9.5 & 9.4 & 9.3 & 9 & 8.9 & 9.1 & 9 & 9 & 8.5 \\
\hline nRBC percentage & 0 & 0 & 0 & 0 & 0 & 0 & 0 & 0 & 0 & 0 & 0 & 0 \\
\hline $\mathrm{nRBC}$ abs & 0 & 0 & 0 & 0 & 0 & 0 & 0 & 0 & 0 & 0 & 0 & 0 \\
\hline Sodium & 126 & 131 & 132 & 132 & 133 & 132 & 127 & 132 & 130 & 129 & 130 & 131 \\
\hline Potassium & 4.3 & 2.9 & 309 & 3.1 & 3.4 & 3.7 & 3.9 & 4.5 & 4.5 & 4.1 & 4.2 & 3.6 \\
\hline Chloride & 93 & 104 & 106 & 99 & 101 & 96 & 95 & 96 & 97 & 97 & 95 & 96 \\
\hline $\mathrm{CO}_{2}$ & 17 & 17 & 15 & 24 & 26 & 27 & 24 & 28 & 19 & 21 & 26 & 27 \\
\hline Anion gap & 16 & 10 & 11 & 9 & 6 & 9 & 8 & 8 & 9 & 11 & 9 & 8 \\
\hline Glucose & 93 & 80 & 90 & 104 & 99 & 99 & 93 & 90 & 78 & 78 & 88 & 104 \\
\hline BUN & 21 & 14 & 13 & 7 & 7 & 7 & 8 & 12 & 12 & 12 & 11 & 6 \\
\hline Creatinine, serum & 0.71 & 0.6 & 0.62 & 0.56 & 0.55 & 0.55 & 0.54 & 0.6 & 0.57 & 0.57 & 0.59 & 0.52 \\
\hline eGR non-African American & 88 & $>90$ & $>90$ & $>90$ & $>90$ & $>90$ & $>90$ & $>90$ & $>90$ & $>90$ & $>90$ & $>90$ \\
\hline Calcium & 8.7 & 7.5 & 7.5 & 8.1 & 8 & 8.8 & 8.6 & 9.5 & 8.3 & 8.5 & 8.8 & 8.2 \\
\hline Bilirubin, total & 1.6 & 1.0 & 1.2 & 1.2 & 1.0 & 1.0 & 1.0 & 0.8 & 0.6 & 06 & 0.4 & 0.3 \\
\hline Protein, total & 6.8 & 5.2 & 5.2 & 5.6 & 5.1 & 6.0 & 6.1 & 6.3 & 5.8 & 6.0 & 6.2 & 5.3 \\
\hline Albumin & 2.5 & 1.9 & 1.9 & 2.0 & 1.8 & 2.1 & 2.1 & 2.3 & 2.5 & 2.1 & 2.2 & 1.9 \\
\hline AST & 213 & 206 & 105 & 49 & 25 & 22 & 24 & 22 & 24 & 19 & 20 & 12 \\
\hline ALT & 57 & 76 & 56 & 42 & 24 & 19 & 17 & 15 & 14 & 11 & 10 & 7 \\
\hline Alkaline phosphatase & 479 & 415 & 401 & 426 & 356 & 453 & 485 & 487 & 453 & 415 & 402 & 253 \\
\hline Magnesium & & 1.8 & 1.4 & 1.8 & 1.4 & 1.5 & 1.4 & 1.6 & 1.6 & 1.7 & 1.7 & 2.1 \\
\hline \multicolumn{13}{|l|}{ Ammonia } \\
\hline Lactate & 1.94 & 0.8 & & & & & & & & & & \\
\hline CRP, inflammatory & 237 & & & & & & & 133.3 & & & & \\
\hline Procalcitonin & 5.48 & & & & & & & & & & & \\
\hline $\mathrm{CK}$, total & 69 & 72 & & & & & & & & & & \\
\hline Osmolality, measured & & & & & & & & & & 262 & & \\
\hline ESR & 104 & & & & & & & 58 & & & & \\
\hline
\end{tabular}

which was complicated by endocarditis as well as prosthetic joint infection. In this particular case, they attempted a salvage approach for the prosthetic joint but were unsuccessful at clearing the infection, indicating that the virulence factors discussed require more aggressive initial interventions for effective treatment.

3.2. Antibiotic Resistance. Drug resistance has been noted in a number of strains infecting bovine and avian species in China [12]. P. multocida strains known to infect humans and cats have been shown to possess resistance to cotrimoxazole (75.6\%), sulfisoxazole (60.9\%), and penicillin (7.3\%), as well as others at very low rates [13]. Furthermore, $\beta$-lactamase production has been documented as well as the presence of plasmids that are associated with resistance to various antibiotic classes including tetracyclines and aminoglycosides [14]. The potential for beta-lactamase production should be noted by physicians when treating $P$. multocida infections or when $P$. multocida is suspected and treatment failure occurs, as beta-lactams are frequently the first line therapies for cellulitis and bacteremia.
3.3. Lenalidomide in the Setting of Infection. In our patient, a history of multiple prosthetic joints significantly elevated the risks associated with bacteremia due to her increased susceptibility to joint seeding. While most documented cases of Pasteurella bacteremia are in patients who suffered animal bites and scratches, there are documented cases in which the source of the infection was considered to be licking of an existing wound or kissing of the animal [3, 4, 13]. Of significant interest is the fact that the patient was taking lenalidomide at the time of hospitalization. In a metaanalysis conducted in 2017, the incidence of high-grade infection in patients with multiple myeloma taking lenalidomide was determined to be $14.32 \%$, nearly twice the infection rate of the control group [15].

While a mechanism for the way in which lenalidomide might lead to immunodeficiency has not yet been established, a number of confounding factors leading to immunodeficiency in patients with multiple myeloma include advanced median age of patients, effects of the disease on $B$ cells, T cells, and natural killer cells, as well as additional medical therapies used in the treatment of multiple myeloma [16]. 


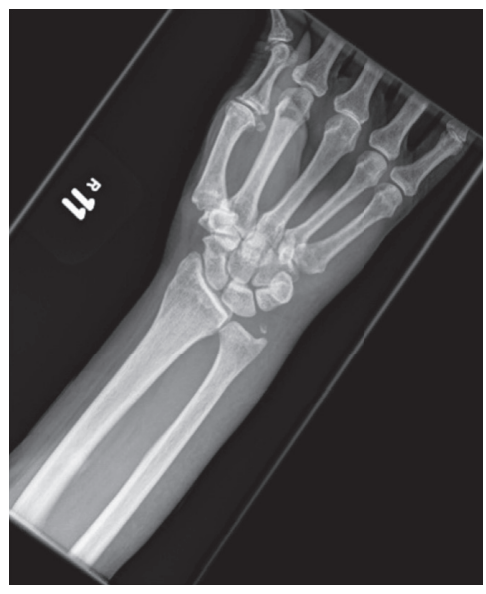

(a)

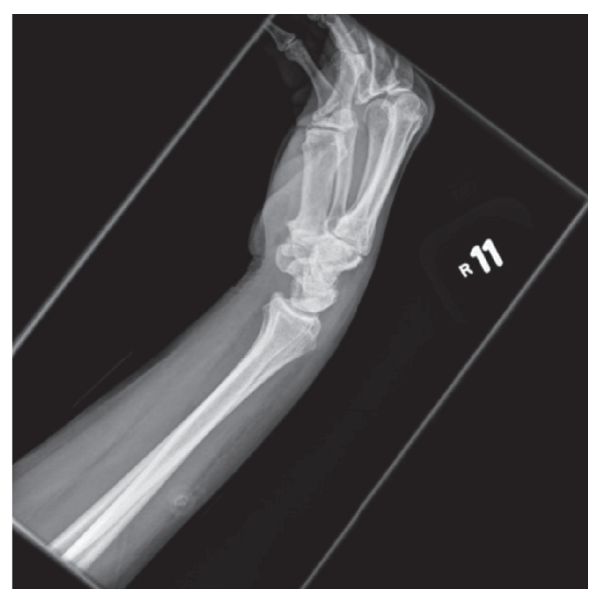

(b)

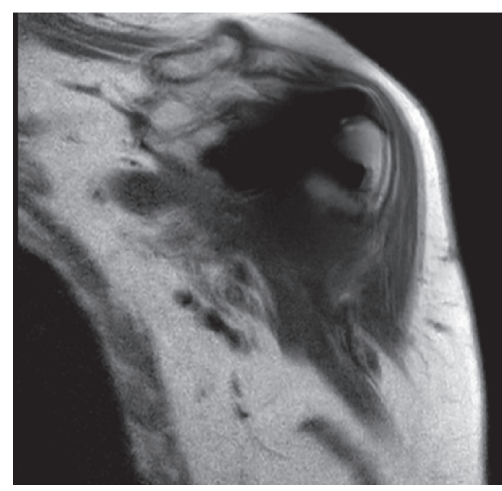

(c)

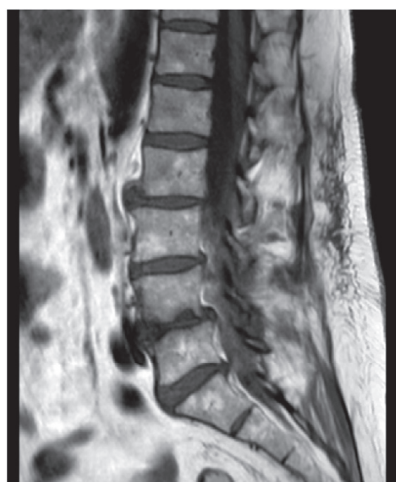

(d)

FIGURE 1: (a) PA X-ray right wrist, (b) lateral X-ray right wrist, (c) T1 coronal MRI right shoulder, and (d) T1 sagittal lumbar spine.

3.4. Prosthetic vs. Native Joint Seeding. The presence of a prosthetic joint in and of itself is an established risk factor for infection [17]. Furthermore, in bacteremia patients, the microbial load required to seed and infect a joint is lower [17]. In a review of literature regarding the seeding of joints by P. multocida from 1985 to 2019 (Table 2), there were 30 cases of infection reported involving a knee joint, seven cases of a hip joint, two cases of shoulder joint (including our patient in this report), one case of ankle joint, and one case of wrist joint. Of these, 28 of 30 (93\%) knee infections were prosthetic, 7 of 7 (100\%) hip infections were prosthetic, 1 of $2(50 \%)$ shoulder infections was prosthetic, 0 of $1(0 \%)$ ankle infection was prosthetic, and 0 of $1(0 \%)$ wrist infection was prosthetic.

The decision of whether to salvage or replace a prosthetic joint after seeding has occurred is a complicated one. In the review described above, 13 joints were debrided with antimicrobials and salvaged, while 29 joints were removed (Table 2). Cost and associated risks with repeated arthroscopic surgery and spacer placement have to be weighed against the risk of chronic infection that a more conservative debridement and salvage may bring. Of the 13 cases in which the joint was salvaged, one death occurred leading to the conclusion that salvage of the joint (and other septic joints in the general population) was a poor decision due to the risk of sepsis that goes with retainment of an infected foreign body [11].
3.5. Meningitis and Septic Arthritis in the Setting of Pasteurella Bacteremia. Review of 13 cases in which meningitis occurred in the setting of P. multocida infection from 1983 to 2018 was conducted to analyze the relationship between meningitis and bacteremia. 10 of $13(77 \%)$ cases occurred in the setting of Pasteurella bacteremia, with the remaining 3 cases not documenting the presence (Table 3).

Based on the review of outcomes from 13 cases, 10 patients had resolution of infection, two patients had negative long-term neurological outcomes, and one patient died (in the setting of HIV infection). These results support consideration of lumbar puncture in patients presenting with evidence of joint infection in the setting of animal contact and immunocompromising illness due to the risk of meningitis.

3.6. Risk Factors and Potential Mechanism. While Pasteurella bacteremia in the absence of a bite or scratch is uncommon, most documented cases were in the presence of some form of immunodeficiency $[3,12]$. A number of risk factors have been established including advanced age (mean age of 63), alcohol consumption, tobacco use, and chronic liver disease [61]. Our patient in this case report demonstrated both age and alcohol risk factors. Our patient denied any bites or scratches, and physical examination corroborated her story; however, there was an abrasion on her right wrist that she 
TAвle 2: Previous findings and outcomes from case reports in relation to the presence of septic arthritis in patients with Pasteurella bacteremia.

\begin{tabular}{|c|c|c|c|c|c|c|c|}
\hline Reference & $\begin{array}{c}\text { Site of } \\
\text { infection }\end{array}$ & $\begin{array}{c}\text { Animal } \\
\text { exposure? }\end{array}$ & Comorbidities & $\begin{array}{c}\text { Duration of } \\
\text { therapy }\end{array}$ & $\begin{array}{l}\text { Antibiotic } \\
\text { resistance? }\end{array}$ & $\begin{array}{c}\text { Bacteremia } \\
(\mathrm{y} / \mathrm{n}) ?\end{array}$ & $\begin{array}{c}\text { Outcome (surgical } \\
\text { intervention?) }\end{array}$ \\
\hline Maurer et al. [18] & $\begin{array}{c}\text { Knee, } \\
\text { prosthetic }\end{array}$ & Yes & $\begin{array}{c}\text { Rheumatoid } \\
\text { arthritis }\end{array}$ & - & None & No & $\begin{array}{c}\text { Cure, no } \\
\text { intervention }\end{array}$ \\
\hline $\begin{array}{l}\text { Griffin and Barber } \\
\text { [19] }\end{array}$ & $\begin{array}{l}\text { Knee, } \\
\text { prosthetic }\end{array}$ & Yes & $\begin{array}{l}\text { Rheumatoid } \\
\text { arthritis }\end{array}$ & - & None & No & $\begin{array}{c}\text { Cure, no } \\
\text { intervention }\end{array}$ \\
\hline $\begin{array}{l}\text { Sugarmen et al. } \\
{[20]}\end{array}$ & $\begin{array}{l}\text { Knee, } \\
\text { prosthetic }\end{array}$ & Yes & $\begin{array}{l}\text { Rheumatoid } \\
\text { arthritis }\end{array}$ & - & None & No & $\begin{array}{c}\text { Cure, replacement } \\
\text { of prosthesis }\end{array}$ \\
\hline $\begin{array}{l}\text { Arvan and } \\
\text { Goldberg [21] }\end{array}$ & $\begin{array}{l}\text { Knee, } \\
\text { prosthetic }\end{array}$ & Yes & Advanced age & - & None & No & $\begin{array}{c}\text { Cure, surgical } \\
\text { debridement }\end{array}$ \\
\hline Spagnuolo [22] & $\begin{array}{l}\text { Knee, } \\
\text { prosthetic }\end{array}$ & Yes & Advanced age & - & None & No & $\begin{array}{l}\text { Cure, surgical } \\
\text { debridement }\end{array}$ \\
\hline $\begin{array}{l}\text { Gomez-Reino } \\
\text { et al. [23] }\end{array}$ & $\begin{array}{l}\text { Knee, } \\
\text { prosthetic }\end{array}$ & Yes & Advanced age & - & None & No & $\begin{array}{c}\text { Cure, replacement } \\
\text { of prosthesis }\end{array}$ \\
\hline $\begin{array}{l}\text { Mellors and } \\
\text { Schoen [24] }\end{array}$ & $\begin{array}{l}\text { Bl knees, } \\
\text { prosthetic }\end{array}$ & Yes & None & - & None & No & Cure, none \\
\hline $\begin{array}{l}\text { Orton and Fulcher } \\
{[25]}\end{array}$ & $\begin{array}{l}\text { Bl knees, } \\
\text { prosthetic }\end{array}$ & Yes & Advanced age & - & None & No & $\begin{array}{c}\text { Cure, replacement } \\
\text { of prosthesis }\end{array}$ \\
\hline Taillan et al. [26] & $\begin{array}{l}\text { Knee, } \\
\text { prosthetic }\end{array}$ & Yes & Advanced age & - & None & No & Cure, none \\
\hline $\begin{array}{l}\text { Braithwaite and } \\
\text { Giddins [27] }\end{array}$ & $\begin{array}{l}\text { Hip, } \\
\text { prosthetic }\end{array}$ & Yes & Diabetes & - & None & No & $\begin{array}{l}\text { Cure, replacement } \\
\text { of prosthesis }\end{array}$ \\
\hline $\begin{array}{l}\text { Guion and Sculco } \\
{[28]}\end{array}$ & $\begin{array}{l}\text { Knee, } \\
\text { prosthetic }\end{array}$ & Yes & $\begin{array}{l}\text { Rheumatoid } \\
\text { arthritis }\end{array}$ & - & None & No & $\begin{array}{l}\text { Cure, replacement } \\
\text { of prosthesis }\end{array}$ \\
\hline $\begin{array}{l}\text { Gabuzda and } \\
\text { Barnett [29] }\end{array}$ & $\begin{array}{l}\text { Knee, } \\
\text { prosthetic }\end{array}$ & Yes & Advanced age & - & None & No & $\begin{array}{c}\text { Cure, replacement } \\
\text { of prosthesis }\end{array}$ \\
\hline Antuña et al. [30] & $\begin{array}{l}\text { Knee, } \\
\text { prosthetic }\end{array}$ & Yes & $\begin{array}{l}\text { Rheumatoid } \\
\text { arthritis }\end{array}$ & - & None & No & $\begin{array}{l}\text { Cure, surgical } \\
\text { debridement }\end{array}$ \\
\hline Takwale et al. [31] & $\begin{array}{l}\text { Hip, } \\
\text { prosthetic }\end{array}$ & Yes & $\begin{array}{l}\text { Rheumatoid } \\
\text { arthritis }\end{array}$ & - & None & No & $\begin{array}{l}\text { Cure, replacement } \\
\text { of prosthesis }\end{array}$ \\
\hline $\begin{array}{l}\text { Maradona et al. } \\
{[32]}\end{array}$ & $\begin{array}{l}\text { L knee, } \\
\text { prosthetic }\end{array}$ & Yes & $\begin{array}{l}\text { Advanced age, } \\
\text { diabetes }\end{array}$ & 3 weeks & None & No & $\begin{array}{c}\text { Cure, surgical } \\
\text { debridement }\end{array}$ \\
\hline Chikwe et al. [33] & $\begin{array}{l}\mathrm{R} \text { hip, } \\
\text { prosthetic }\end{array}$ & Yes & Advanced age & - & None & No & $\begin{array}{c}\text { Cure, replacement } \\
\text { of prosthesis }\end{array}$ \\
\hline $\begin{array}{l}\text { Ciampolini et al. } \\
\text { [34] }\end{array}$ & $\begin{array}{l}\text { Knee, } \\
\text { prosthetic }\end{array}$ & Yes & Advanced age & 6 weeks & None & No & $\begin{array}{l}\text { Cure, replacement } \\
\text { of prosthesis }\end{array}$ \\
\hline $\begin{array}{l}\text { Polzhoferet al. } \\
{[35]}\end{array}$ & $\begin{array}{l}\mathrm{R} \text { knee, } \\
\text { prosthetic }\end{array}$ & Yes & Advanced age & - & None & No & $\begin{array}{l}\text { Cure, surgical } \\
\text { debridement }\end{array}$ \\
\hline Stiehl et al. [36] & $\begin{array}{l}\text { Knee, } \\
\text { prosthetic }\end{array}$ & Yes & Advanced age & - & None & No & $\begin{array}{l}\text { Cure, replacement } \\
\text { of prosthesis }\end{array}$ \\
\hline $\begin{array}{l}\text { Mehta and Mackie } \\
\text { [37] }\end{array}$ & $\begin{array}{l}\text { Hip, } \\
\text { prosthetic }\end{array}$ & Yes & $\begin{array}{l}\text { Advanced age, } \\
\text { rheumatoid } \\
\text { arthritis }\end{array}$ & - & None & No & $\begin{array}{l}\text { Cure, replacement } \\
\text { of prosthesis }\end{array}$ \\
\hline $\begin{array}{l}\text { Mehta and Mackie } \\
\text { [37] }\end{array}$ & $\begin{array}{l}\text { Hip, } \\
\text { prosthetic }\end{array}$ & Yes & $\begin{array}{l}\text { Rheumatoid } \\
\text { arthritis }\end{array}$ & - & None & No & $\begin{array}{l}\text { Cure, replacement } \\
\text { of prosthesis }\end{array}$ \\
\hline Heym et al. [38] & $\begin{array}{l}\text { Knee, } \\
\text { prosthetic }\end{array}$ & Yes & Advanced age & 2 months & None & Yes & $\begin{array}{c}\text { Cure, replacement } \\
\text { of prosthesis }\end{array}$ \\
\hline $\begin{array}{l}\text { Kadakia and } \\
\text { Langkamer [39] }\end{array}$ & $\begin{array}{l}\text { Knee, } \\
\text { prosthetic }\end{array}$ & Yes & Advanced age & 10 weeks & None & No & $\begin{array}{c}\text { Cure, surgical } \\
\text { debridement }\end{array}$ \\
\hline $\begin{array}{l}\text { Heydeman et al. } \\
{[40]}\end{array}$ & $\begin{array}{l}\text { L knee, } \\
\text { prosthetic }\end{array}$ & Yes & Advanced age & 4 weeks & None & No & $\begin{array}{c}\text { Cure, removal of } \\
\text { prosthesis }\end{array}$ \\
\hline Romano et al. [41] & $\begin{array}{l}\text { L knee, } \\
\text { prosthetic }\end{array}$ & Yes & $\begin{array}{l}\text { Advanced age, } \\
\text { rheumatoid } \\
\text { arthritis }\end{array}$ & 6 weeks & None & Yes & $\begin{array}{c}\text { Cure, surgical } \\
\text { debridement }\end{array}$ \\
\hline $\begin{array}{l}\text { Furgeson et al. } \\
{[42]}\end{array}$ & $\begin{array}{l}\text { L knee, } \\
\text { prosthetic }\end{array}$ & Yes & Advanced age & 8 weeks & None & No & $\begin{array}{l}\text { Cure, surgical } \\
\text { debridement }\end{array}$ \\
\hline $\begin{array}{l}\text { Ayoade and Todd. } \\
\text { [17] }\end{array}$ & $\begin{array}{l}\mathrm{R} \text { knee, } \\
\text { prosthetic }\end{array}$ & Yes & $\begin{array}{l}\text { Advanced age, } \\
\text { obesity, aortic } \\
\text { stenosis }\end{array}$ & 7 days & None & Yes & $\begin{array}{l}\text { Death, surgical } \\
\text { debridement }\end{array}$ \\
\hline
\end{tabular}


TABLE 2: Continued.

\begin{tabular}{|c|c|c|c|c|c|c|c|}
\hline Reference & $\begin{array}{c}\text { Site of } \\
\text { infection }\end{array}$ & $\begin{array}{c}\text { Animal } \\
\text { exposure? }\end{array}$ & Comorbidities & $\begin{array}{c}\text { Duration of } \\
\text { therapy }\end{array}$ & $\begin{array}{l}\text { Antibiotic } \\
\text { resistance? }\end{array}$ & $\begin{array}{c}\text { Bacteremia } \\
(\mathrm{y} / \mathrm{n}) ?\end{array}$ & $\begin{array}{c}\text { Outcome (surgical } \\
\text { intervention?) }\end{array}$ \\
\hline $\begin{array}{l}\text { Arbefeville et al. } \\
\text { [43] }\end{array}$ & $\begin{array}{l}\mathrm{R} \text { knee, } \\
\text { prosthetic }\end{array}$ & Yes & Advanced age & 6 weeks & None & yes & $\begin{array}{l}\text { Cure, replacement } \\
\text { of prosthesis }\end{array}$ \\
\hline $\begin{array}{l}\text { Zahirovic and } \\
\text { Siddique [44] }\end{array}$ & L wrist, native & Yes & Diabetes & 2 weeks & $\begin{array}{c}\text { Yes (to } \\
\text { erythromycin) }\end{array}$ & Yes & $\begin{array}{c}\text { Cure, surgical } \\
\text { debridement }\end{array}$ \\
\hline $\begin{array}{l}\text { Honnerat et al. } \\
\text { [45] }\end{array}$ & $\begin{array}{l}\text { Hip, } \\
\text { prosthetic }\end{array}$ & Yes & Advanced age & 8 months & None & No & $\begin{array}{l}\text { Cure, surgical } \\
\text { debridement }\end{array}$ \\
\hline $\begin{array}{l}\text { Honnerat et al. } \\
{[45]}\end{array}$ & $\begin{array}{l}\text { Knee, } \\
\text { prosthetic }\end{array}$ & Yes & $\begin{array}{c}\text { Advanced age, } \\
\text { diabetes }\end{array}$ & 8 months & None & No & $\begin{array}{l}\text { Cure, replacement } \\
\text { of prosthesis }\end{array}$ \\
\hline $\begin{array}{l}\text { Honnerat et al. } \\
{[45]}\end{array}$ & $\begin{array}{l}\text { Knee, } \\
\text { prosthetic }\end{array}$ & Yes & $\begin{array}{c}\text { Advanced age, } \\
\text { diabetes }\end{array}$ & 8 months & None & No & $\begin{array}{l}\text { Cure, replacement } \\
\text { of prosthesis }\end{array}$ \\
\hline $\begin{array}{l}\text { Honnerat et al. } \\
{[45]}\end{array}$ & $\begin{array}{l}\text { Knee, } \\
\text { prosthetic }\end{array}$ & Yes & $\begin{array}{l}\text { Advanced age, } \\
\text { obesity }\end{array}$ & 8 months & None & No & $\begin{array}{l}\text { Cure, replacement } \\
\text { of prosthesis }\end{array}$ \\
\hline $\begin{array}{l}\text { Honnerat et al. } \\
{[45]}\end{array}$ & $\begin{array}{l}\text { Knee, } \\
\text { prosthetic }\end{array}$ & Yes & Advanced age & 8 months & None & No & $\begin{array}{c}\text { Cure, surgical } \\
\text { debridement }\end{array}$ \\
\hline $\begin{array}{l}\text { Honnerat et al. } \\
\text { [45] }\end{array}$ & $\begin{array}{l}\text { Knee, } \\
\text { prosthetic }\end{array}$ & Yes & Advanced age & 8 months & None & No & $\begin{array}{l}\text { Cure, replacement } \\
\text { of prosthesis }\end{array}$ \\
\hline $\begin{array}{l}\text { Nitorslawski et al. } \\
\text { [46] }\end{array}$ & $\begin{array}{l}\text { Knee, native; } \\
\text { shoulder, } \\
\text { native }\end{array}$ & Yes & Advanced age & 6 weeks & None & No & $\begin{array}{l}\text { Cure, surgical } \\
\text { debridement }\end{array}$ \\
\hline Fayyaz [47] & $\begin{array}{l}\text { L hip, } \\
\text { prosthetic }\end{array}$ & No & COPD, alcohol use & 6 weeks & None & Yes & $\begin{array}{l}\text { Cure, replacement } \\
\text { of prosthesis }\end{array}$ \\
\hline $\begin{array}{l}\text { Katechakis et al. } \\
{[48]}\end{array}$ & $\begin{array}{l}\text { Ankle and } \\
\text { knee, native }\end{array}$ & Yes & None & 20 days & None & Yes & $\begin{array}{l}\text { Cure, below the } \\
\text { knee amputation }\end{array}$ \\
\hline & & & Alcohol use, & & & & \\
\hline
\end{tabular}

TABLE 3: Previous findings and outcomes from case reports in relation to the presence of meningitis in patients with Pasteurella bacteremia.

\begin{tabular}{|c|c|c|c|c|c|c|c|c|}
\hline Reference & Year & $\begin{array}{l}\text { Presenting } \\
\text { compliant }\end{array}$ & $\begin{array}{c}\text { Site of } \\
\text { infection }\end{array}$ & $\begin{array}{c}\text { Animal } \\
\text { exposure? }\end{array}$ & Comorbidities & $\begin{array}{l}\text { Antibiotic } \\
\text { resistance? }\end{array}$ & $\begin{array}{l}\text { Bacteremia } \\
\quad(\mathrm{y} / \mathrm{n}) ?\end{array}$ & Outcome \\
\hline $\begin{array}{l}\text { Nitoslawski et al. } \\
{[46]}\end{array}$ & 2018 & Fever & CNS & Yes & $\begin{array}{l}\text { Diabetes } \\
\text { mellitus }\end{array}$ & No & Yes & Cure \\
\hline Larné et al. [49] & 2019 & Fever & CNS & Yes & & No & Yes & Cure \\
\hline Clarke et al. [2] & 2017 & Fever & CNS & Yes & & No & Yes & $\begin{array}{l}\text { Cure, residual } \\
\text { hearing loss }\end{array}$ \\
\hline $\begin{array}{l}\text { Yamaguchi et al. } \\
\text { [50] }\end{array}$ & 2014 & Fever & CNS & Yes & None & No & Yes & Cure \\
\hline $\begin{array}{l}\text { Spadafora et al. } \\
\text { [51] }\end{array}$ & 2011 & $\begin{array}{l}\text { Status } \\
\text { epilepticus }\end{array}$ & CNS & Yes & & No & No & Cure \\
\hline Soloaga et al. [52] & 2008 & Fever & CNS & Yes & & No & Yes & Cure \\
\hline Hirsh et al. [53] & 2004 & Fever & CNS & Yes & None & No & No & Cure \\
\hline Green et al. [54] & 2002 & & CNS & Yes & & No & Yes & Cure \\
\hline Layton [55] & 1999 & Fever & CNS & Yes & & No & Yes & Cure \\
\hline Guerin et al. [56] & 1994 & & CNS & Yes & $\mathrm{HIV}+$ & No & Yes & Death \\
\hline Kumar et al. [57] & 1990 & & CNS & Yes & & No & Yes & Cure \\
\hline Levy et al. [58] & 1989 & Fever & CNS & Yes & None & No & Yes & $\begin{array}{c}\text { Cure, residual } \\
\text { neurological deficit }\end{array}$ \\
\hline $\begin{array}{l}\text { Permezel et el. } \\
\text { [59] }\end{array}$ & 1984 & Fever & CNS & Yes & $\begin{array}{l}\text { Recent sinus } \\
\text { surgery }\end{array}$ & No & No & Cure \\
\hline $\begin{array}{l}\text { Bruun and Friis- } \\
\text { Møller [60] }\end{array}$ & 1983 & Fever & CNS & Yes & Chronic om & No & No & Cure \\
\hline
\end{tabular}

sustained from her prior fall. In support of the hypothesis that the licking of an already existing wound led to infection with $P$. multocida, the patient has multiple dogs and cats and reported that one cat has a tendency to lick people and objects. Cases in which licking was considered to be a likely mode of transmission have been documented [4, 62]. Additionally, one retrospective review noted that cases of
P. multocida bacteremia where animal bites were not noted as the inciting event for infection were found to have poorer outcomes [63]. Given our patient's hospital course, we would hypothesize that her infection was related to licking of a preexisting wound, with underlying comorbidities portending a more aggressive course and potentially a worse prognosis. 
3.7. Thrombocytopenia in the Setting of Infection. The patient was thrombocytopenic on initial labs taken in the emergency department. This resolved by day 3 of admission, and the patient had a normal platelet count for the duration of her hospital stay. A number of mechanisms have been postulated to account for thrombocytopenia in systemic infection including the formation of thrombocyte/neutrophil complexes and the temporary reduction of thrombopoiesis due to LPS $[64,65]$. The role of platelets in infection has been reviewed at length by Dewitte et al. [66]. Given that this patient had a Gram-negative bacteremia, we suspect her temporary thrombocytopenia may have been due to a combination of thrombocyte/neutrophil aggregation and the effects of LPS on thrombopoiesis.

\section{Conclusion}

Given the relative abundance of cats and dogs as pets in the United States, it is prudent to remain aware of zoonotic pathogens. P. multocida is a microorganism with the capability of causing infection associated with significant morbidity and mortality. With pet ownership in the United States unlikely to decline in the near future, it is important to consider $P$. multocida in patients who have contact with pets and comorbid factors known to attenuate immunity. Physicians treating patients found to be infected with P. multocida should be aware of the potential for bacteremia, prosthetic joint infection, and meningitis, particularly in patients with advanced age and immunocompromised states as demonstrated by our patient.

\section{Abbreviations}

g/dL: $\quad$ Grams per deciliter

$\mathrm{mMol} / \mathrm{L}$ : Millimoles per liter

IU/L: International units per liter

MRI: $\quad$ Magnetic resonance imaging

CT: $\quad$ Computed tomography

LPS: Lipopolysaccharide.

\section{Consent}

The patient's informed consent for publication and participation was obtained.

\section{Conflicts of Interest}

The authors declare that they have no conflicts of interest.

\section{Authors' Contributions}

William F. Abel, Christopher S. Eckman, DO, Robert P. Summers, and William S. Sessions, MD, MBA, were responsible for the content and editing of this work. Amanda E. Schnee, MD, contributed to the content and provided expertise and editing in the fields of internal medicine and infectious disease.

\section{Acknowledgments}

This study was funded by the Prisma Health Upstate Department of Medicine.

\section{References}

[1] D. A. Talan, D. M. Citron, F. M. Abrahamian, G. J. Moran, and E. J. C. Goldstein, "Bacteriologic analysis of infected dog and cat bites," New England Journal of Medicine, vol. 340, no. 2, pp. 85-92, 1999.

[2] D. A. Clarke, A. Mcbride, M. Kelsey, and B. Killingley, "Pasteurella multocidameningoencephalitis in an immunocompetent adult with multiple cat scratches," BMJ Case Reports, vol. 2017, 2017.

[3] R. Kimura, Y. Hayashi, T. Takeuchi et al., "Pasteurella multocida septicemia caused by close contact with a domestic cat: case report and literature review," Journal of Infection and Chemotherapy, vol. 10, no. 4, pp. 250-252, 2004.

[4] F. Zarlasht and M. Khan, "A case of recurrent Pasteurella bacteremia in an immunocompetent patient with no animal bite," The American Journal of Case Reports, vol. 19, pp. 95-98, 2018.

[5] F. M. Collins, "Pasteurella, Yersinia, and Francisella," in Medical Microbiology, University of Texas Medical Branch, Galveston, TX, USA, 1996.

[6] American Veterinary Medical Association, U.S. Pet Ownership Statistics, American Veterinary Medical Association, Schaumburg, IL, USA, 2018.

[7] J. Ebright, A. B. Frey, and M. R. Fairfax, "Pasteurella multocida infections and bacteremia," Infectious Diseases in Clinical Practice, vol. 17, no. 2, pp. 102-104, 2009.

[8] M. Harper and J. D. Boyce, "The myriad properties of Pasteurella multocida lipopolysaccharide," Toxins, vol. 9, no. 8, 2017.

[9] B. Ujvári, R. Weiczner, Z. Deim et al., "Characterization of Pasteurella multocida strains isolated from human infections," Comparative Immunology, Microbiology and Infectious Diseases, vol. 63, pp. 37-43, 2019.

[10] B. Petruzzi, R. E. Briggs, W. E. Swords et al., "Capsular polysaccharide interferes with biofilm formation by Pasteurella multocida serogroup A," Microbiology, vol. 8, no. 6, 2017.

[11] M. Guilbart, E. Zogheib, A. Hchikat et al., "Fatal multifocal Pasteurella multocida infection: a case report," BMC Research Notes, vol. 8, no. 1, p. 287, 2015.

[12] Z. Wang, L.-C. Kong, B.-Y. Jia, S.-M. Liu, X.-Y. Jiang, and H.-X. Ma, "Aminoglycoside susceptibility of Pasteurella multocida isolates from bovine respiratory infections in China and mutations in ribosomal protein S5 associated with highlevel induced spectinomycin resistance," Journal of Veterinary Medical Science, vol. 79, no. 10, pp. 1678-1681, 2017.

[13] T. S. P. Ferreira, M. R. Felizardo, D. D. S. D. Gobbi, M. Moreno, and A. M. Moreno, "Antimicrobial resistance and virulence gene profiles in P. multocida strains isolated from cats," Brazilian Journal of Microbiology, vol. 46, no. 1, pp. 271-277, 2015.

[14] A. San Millan, J. A. Escudero, B. Gutierrez et al., "Multiresistance in Pasteurella multocida is mediated by coexistence of small plasmids," Antimicrobial Agents and Chemotherapy, vol. 53, no. 8, pp. 3399-3404, 2009.

[15] L. Ying, T. YinHui, Z. Yunliang, and H. Sun, "Lenalidomide and the risk of serious infection in patients with multiple 
myeloma: a systematic review and meta-analysis," Oncotarget, vol. 8, no. 28, pp. 46593-46600, 2017.

[16] M. Kleber, G. Ihorst, M. Terhorst et al., "Comorbidity as a prognostic variable in multiple myeloma: comparative evaluation of common comorbidity scores and use of a novel MM-comorbidity score," Blood Cancer Journal, vol. 1, no. 9, p. e35, 2011.

[17] F. Ayoade and J. R. Todd, Prosthetic Joint Infection, StatPearls, Treasure Island, FL, USA, 2017.

[18] K. Maurer, P. Hasselbacher, and H. R. Schumacher, "Joint infection by Pasteurella multocida," The Lancet, vol. 306, no. 7931, p. 409, 1975.

[19] A. J. Griffin and H. M. Barber, "Letter: joint infection by pasteurella multocida," The Lancet, vol. 305, no. 7920, pp. 1347-1348, 1975.

[20] M. Sugarman, F. P. Quismorio, and M. J. Patzakis, "Letter: joint infection by Pasteurella multocida," Lancet (London, England), vol. 2, no. 7947, p. 1267, 1975.

[21] G. D. Arvan and V. Goldberg, "A case report of total knee arthroplasty infected by Pasteurella multocida," Clinical Orthopaedics and Related Research, no. 132, pp. 167-169, 1978.

[22] P. J. Spagnuolo, "Pasteurella multocida infectious arthritis," The American Journal of the Medical Sciences, vol. 275, no. 3, pp. 359-363, 1978.

[23] J. J. Gomez-Reino, M. Shah, P. Gorevic, and R. Lusskin, "Pasteurella multocida arthritis. Case report," The Journal of Bone \& Joint Surgery. American Volume, vol. 62, no. 7, pp. 1212-1213, 1980.

[24] J. W. Mellors and R. T. Schoen, "Pasteurella multocida prosthetic joint infection," Annals of Emergency Medicine, vol. 14 , no. 6, p. 617, 1985.

[25] D. W. Orton and W. H. Fulcher, "Pasteurella multocida: bilateral septic knee joint prostheses from a distant cat bite," Annals of Emergency Medicine, vol. 13, no. 11, pp. 1065-1067, 1984.

[26] B. Taillan, J. P. Jullien, J. G. Fuzibet et al., "Septic arthritis due to Pasteurella multocida. 3 new case reports," Revue Du Rhumatisme Et Des Maladies Osteo-Articulaires, vol. 55, no. 12, pp. 1037-1038, 1988.

[27] B. D. Braithwaite and G. Giddins, "Pasteurella multocida infection of a total hip arthroplasty," The Journal of Arthroplasty, vol. 7, no. 3, pp. 309-310, 1992.

[28] T. L. Guion and T. P. Sculco, "Pasteurella multocida infection in total knee arthroplasty," The Journal of Arthroplasty, vol. 7, no. 2, pp. 157-160, 1992.

[29] G. M. Gabuzda and P. R. Barnett, "Pasteurella infection in a total knee arthroplasty," Orthopaedic Review, vol. 21, no. 5, pp. 601-605, 1992.

[30] S. A. Antuña, J. G. Méndez, J. L. Castellanos, and J. P. Jimenez, "Late infection after total knee arthroplasty caused by Pasteurella multocida," Acta Orthopaedica Belgica, vol. 63, no. 4, pp. 310-312, 1997.

[31] V. J. Takwale, E. D. Wright, J. Bates, and A. J. Edge, "Pasteurella multocida infection of a total hip arthroplasty following cat scratch," Journal of Infection, vol. 34, no. 3, pp. 263-264, 1997.

[32] J. A. Maradona, V. Asensi, J. A. Carton, A. R. Guardado, and J. L. Castellano, "Prosthetic joint infection by Pasteurella multocida," European Journal of Clinical Microbiology \& Infectious Diseases, vol. 16, no. 8, pp. 623-625, 1997.

[33] J. Chikwe, M. Bowditch, R. N. Villar, and A. F. Bedford, "Sleeping with the enemy: pasteurella multocida infection of a hip replacement," Journal of the Royal Society of Medicine, vol. 93, no. 9, pp. 478-479, 2000.
[34] J. Ciampolini, M. Morgan, and J. Timperley, "Prosthetic joint infection by cat scratch," Journal of the Royal Society of Medicine, vol. 97, no. 9, pp. 441-442, 2004.

[35] G. K. Polzhofer, J. Hassenpflug, and W. Petersen, “Arthroscopic treatment of septic arthritis in a patient with posterior stabilized total knee arthroplasty," Arthroscopy: The Journal of Arthroscopic \& Related Surgery, vol. 20, no. 3, pp. 311-313, 2004.

[36] J. B. Stiehl, L. A. Sterkin, and C. F. Brummitt, "Acute Pasteurella multocida in total knee arthroplasty," The Journal of Arthroplasty, vol. 19, no. 2, pp. 244-247, 2004.

[37] H. Mehta and I. Mackie, "Prosthetic joint infection with Pasturella multocida following cat scratch," The Journal of Arthroplasty, vol. 19, no. 4, pp. 525-527, 2004.

[38] B. Heym, F. Jouve, M. Lemoal, A. Veil-Picard, A. Lortat-Jacob, and M. H. Nicolas-Chanoine, "Pasteurella multocida infection of a total knee arthroplasty after a "dog lick", Knee Surgery, Sports Traumatology, Arthroscopy, vol. 14, no. 10, pp. 993-997, 2006.

[39] A. P. Kadakia and V. G. Langkamer, "Sepsis of total knee arthroplasty after domestic cat bite: should we warn patients?" American Journal of Orthopedics (BelleMead, N.J.), vol. 37, no. 7, pp. 370-371, 2008.

[40] J. Heydemann, J. S. Heydemann, and S. Antony, “Acute infection of a total knee arthroplasty caused by Pasteurella multocida: a case report and a comprehensive review of the literature in the last 10 years," International Journal of Infectious Diseases, vol. 14, no. Suppl 3, pp. e242-e245, 2010.

[41] C. L. Romanò, E. De Vecchi, C. Vassena, G. Manzi, and L. Drago, "A case of a late and atypical knee prosthetic infection by no-biofilm producer Pasteurella multocida strain identified by pyrosequencing," Polish Journal of Microbiology, vol. 62, no. 4, pp. 435-438, 2013.

[42] K. Ferguson, R. Bharadwaj, A. MacDonald, B. Syme, and A. Bal, "Pasteurella multocida infected total knee arthroplasty: a case report and review of the literature," The Annals of The Royal College of Surgeons of England, vol. 96, no. 2, pp. e1-e4, 2014.

[43] S. Arbefeville, A. Harris, S. Dittes, and P. Ferrieri, "Pasteurella multocida bacteremia with associated knee arthroplasty infection in an 80-year-old caucasian man," Laboratory Medicine, vol. 47, no. 3, pp. 241-245, 2016.

[44] S. Zahirovic and F. Siddique, "A tale of two thumbs, a dog, and a wooden table," Arthritis Care \& Research, vol. 69, no. 6, pp. 912-914, 2017.

[45] E. Honnorat, P. Seng, H. Savini, P.-O. Pinelli, F. Simon, and A. Stein, "Prosthetic joint infection caused by Pasteurella multocida: a case series and review of literature," BMC Infectious Diseases, vol. 16, no. 1, p. 435, 2016.

[46] S. Nitoslawski, T. M. McConnell, M. Semret, and M. A. Stein, "A case of polyarticular Pasteurella multocida septic arthritis," Canadian Journal of Infectious Diseases and Medical Microbiology, vol. 2016, Article ID 5025697, 3 pages, 2016.

[47] B. Fayyaz, "Non-zoonotic' Pasteurella multocida infection in an immunocompromised patient," Journal of Community Hospital Internal Medicine Perspectives, vol. 8, no. 6, pp. $370-372,2018$.

[48] N. Katechakis, S. Maraki, I. Dramitinou, E. Marolachaki, C. Koutla, and E. Ioannidou, "An unusual case of Pasteurella multocida bacteremic meningitis," Journal of Infection and Public Health, vol. 12, no. 1, pp. 95-96, 2019.

[49] D. Larnè, M. Ceccarelli, F. Condorelli, E. Venanzi Rullo, G. Nunnari, and G. F. Pellicanò, "Bacteremic meningitis due to Pasteurella multocida resistant to first line antibiotic 
therapy," Infectious Disease Reports, vol. 10, no. 2, p. 7632, 2018.

[50] H. Yamaguchi, T. Tamura, M. Abe et al., "Prolonged incubation period in neonatal pasteurella multocida meningitis and bacteremia," Pediatrics International, vol. 56, no. 6, pp. e79-e81, 2014.

[51] R. Spadafora, G. Pomero, A. Delogu, L. Gozzoli, and P. Gancia, "A rare case of neonatal sepsis/meningitis caused by Pasteurella multocida complicated with status epilepticus and focal cerebritis," La Pediatria Medica E Chirurgica: Medical and Surgical Pediatrics, vol. 33, no. 4, pp. 199-202, 2011.

[52] R. Soloaga, N. Carrión, J. Pidone et al., "(Pasteurella multocida bacteremic meningitis)," Revista Argentina De Microbiologia, vol. 40, no. 4, pp. 208-210, 2008.

[53] D. C. Hirsch, N. MacLachlan, and R. Walker, "Pasteurellaceae Pasteurella, Mannheimia," Veterinary Microbiology, pp. 8490, 2004.

[54] B. T. Green, K. M. Ramsay, and P. E. Nolan, "Pasteurella multocida meningitis: case report and review of the last $11 \mathrm{y}$," Scandinavian Journal of Infectious Diseases, vol. 34, no. 3, pp. 213-217, 2002.

[55] C. T. Layton, "Pasteurella multocida meningitis and septic arthritis secondary to a cat bite," The Journal of Emergency Medicine, vol. 17, no. 3, pp. 445-448, 1999.

[56] J. M. Guerin, A. Mofredj, L. Raskine, and F. Leibinger, "(Septicemia and purulent meningitis caused by pasteurella multocida in a HIV positive patient)," Presse Medicale (Paris, France: 1983), vol. 23, no. 13, p. 631, 1994

[57] A. Kumar, H. R. Devlin, and H. Vellend, "Pasteurella multocida meningitis in an adult: case report and review," Clinical Infectious Diseases, vol. 12, no. 3, pp. 440-448, 1990.

[58] C. E. Levy, K. Irino, C. R. Funayama, and M. V. L. MouraRibeiro, "Meningencefalite por Pasteurella multocida: estudo clínico-laboratorial de um caso em lactente," Arquivos De Neuro-Psiquiatria, vol. 47, no. 4, pp. 468-470, 1989.

[59] J. M. H. Permezel, C. C. Smith, E. Flint, and H. A. Young, "Opportunistic pasteurella multocida meningitis," The Journal of Laryngology \& Otology, vol. 98, no. 9, pp. 939-940, 1984.

[60] B. Bruun and A. Friis-Møller, "Meningitis and bacteremia caused by pasteurella multocida," A Case Report. Acta Pathologica, Microbiologica, Et Immunologica Scandinavica.Section B, Microbiology, vol. 91, no. 5, pp. 329-331, 1983.

[61] V. Nollet, L. Souply, B. Rosolen, M. Mohseni-Zadeh, and M. Martinot, "Risk factors for invasive Pasteurellosis: a retrospective case study," European Journal of Clinical Microbiology \& Infectious Diseases, vol. 35, no. 12, pp. 1975-1981, 2016.

[62] S. Kukrety, J. Parekh, and T. Townley, "Pasteurella multocida Bacteremia in an immunocompromised patient," Case Reports in Medicine, vol. 2016, Article ID 7392847, 3 pages, 2016.

[63] A. Giordano, T. Dincman, B. E. Clyburn, L. L. Steed, and D. C. Rockey, "Clinical features and outcomes of Pasteurella multocida infection," Medicine, vol. 94, no. 36, Article ID e1285, 2015.

[64] S. Russwurm, J. Vickers, A. Meier-Hellmann et al., "Platelet and leukocyte activation correlate with the severity of septic organ dysfunction," Shock, vol. 17, no. 4, pp. 263-268, 2002.

[65] P. Stohlawetz, C. C. Folman, A. E. G. K. Von dem Borne et al., "Effects of endotoxemia on thrombopoiesis in men," Thrombosis and Haemostasis, vol. 81, no. 4, pp. 613-617, 1999.

[66] A. Dewitte, S. Lepreux, J. Villeneuve et al., "Blood platelets and sepsis pathophysiology: a new therapeutic prospect in critically (corrected) ill patients?" Annals of Intensive Care, vol. 7, no. 1, p. 115, 2017. 